\title{
Population features of sex and stress hormones levels in young men blood serum
}

\author{
L.D. Popova, I.M. Vasylyeva, O.A. Nakonechnaya \\ Kharkiv National Medical University, Ukraine; e-mail: popova_ld@ukr.net
}

\begin{abstract}
Testosterone, estradiol, noradrenaline, adrenaline, cortisol levels in blood serum of Ukrainian and Indian young men and interrelations between those parameters, neuroticism and physical aggression were studied. Higher noradrenaline and estradiol contents were revealed in Indian men population as compared with Ukrainian one. Both in total group of participants and men of every population no interrelation between investigated parameters and neuroticism was found, but in Indian men the strong negative correlation between noradrenaline and physical aggression was observed. After division of all participants into 3 subgroups depending on neuroticism level, in persons with high neuroticism the significant positive correlation between neuroticism and cortisol and significant negative correlations between noradrenaline and neuroticism, between noradrenaline and physical aggression were observed. In individuals with middle neuroticism level the strong positive correlations between estradiol and neuroticism and between testosterone and physical aggression were found. Obtained results indicate the different contribution of cortisol and estradiol to formation of high and middle neuroticism levels. The increased content of noradrenaline in men of Indian population appears to provide the potent control of neuroticism and physical aggression expression. In all subgroups (Ukrainian and Indian men, persons with high and middle neuroticism) the strong positive correlation between testosterone to noradrenaline ratio and cortisol to noradrenaline ratio was found.

Key words: sex hormones; stress hormones; neuroticism; physical aggression; men.
\end{abstract}

\section{INTRODUCTION}

Aggression is characteristic for both animals and human. In normal ranges it is necessary for providing individual survival, but excessive aggression is dangerous for both individuals and society.

Two main human excessive aggression forms are described: impulsive and premeditated [1]. The aggression formation mechanisms investigation is very important for understanding excessive aggression manifestations.

According to some literature data, both high impulsive [2, 3] and premeditated [3] aggressions are associated with high neuroticism. In perinatal period testosterone has organizational effects on neural circuits [4] expressed by aggressive behavior in adults [5]. These effects are realized through aromatization of testicular testosterone into $\beta$-estradiol in specific regions of brain [6]. It triggers a second period of structural reorganization and plasticity in the brain in puberty [7]. Testosterone modulates neural circuits in adults [1].

Catecholamines and glucocorticoids are involved in stress reaction and influence the neurobehavioral functions in different brain areas $[1,8,9]$. Noradrenaline exerts a significant influence on early brain development by means of regulation of neurogenesis, migration, differentiation, plasticity and other key morphogenetic processes [10]. Monoaminergic system provides homeostasis both brain and whole organism [11]. It greatly influences human and animal emotions and behavior $[1,8]$. An activation of hypothalamic pituitary adrenal axis in response to physical and emotional stress is accompanied by numerous neuronal and emotional responses aimed at maintaining homeostasis [12].

(C) L.D. Popova, I.M. Vasylyeva, O.A. Nakonechnaya 
The aim of work was the investigation of testosterone, estradiol, noradrenaline, adrenaline, cortisol levels in blood serum of Ukrainian and Indian young men and interrelations between those parameters, neuroticism and physical aggression.

\section{METHODS}

The study involved 32 young men of Ukrainian and Indian populations aged 18 to 22 years. Neuroticism and physical aggression were estimated using Eysenck Personality Inventory and Buss-Durkee Hostility Inventory.

Buss-Durkee Hostility Inventory is used to study aggression. Physical aggression was assessed in a percentage of the maximum level.

Eysenck Personality Inventory provides the estimation of extraversion-introversion and emotional stability-instability (neuroticism). The level of neuroticism was estimated in points. After processing the answers to Eysenck Personality Inventory, we determined the level of neuroticism in each participant in the study. According to the results obtained, we divided the general group into three subgroups depending on the neuroticism level (low level of neuroticism - less than 7 points, middle level of neuroticism - 8-13 points, high level of neuroticism- more than 14 points).

Eysenck Personality Inventory provides to estimate the answers sincerity. If the answers have not been sincere, they were not taken into account during the correlation analysis between physical aggression or neuroticism and investigated hormones in total group, in Ukrainian men, in Indian men, and during the correlation analysis between all parameters in subgroups with middle neuroticism and high neuroticism. Correlation analysis between investigated parameters in persons with low neuroticism was not carried out because of few such individuals.

Hormone levels in blood serum were determined by Testosterone, Estradiol, Cortisol ELISA kits (Italy), Noradrenaline (NA), Epinephrine/Adrenaline (EPI) ELISA kits (China).

Statistical analysis of the results was carried out by methods of nonparametric statistics using the pack- age "Statistica 6.0". Mann-Whitney test was used to compare groups in pairs. Correlation analysis according to Spearman was used to reveal the relationship between different variables of the same group.

\section{RESULTS}

Both in total group of participants and men of every population no interrelation between investigated parameters and neuroticism was found, but in Indian men the strong negative correlation between noradrenaline and physical aggression was observed $(\mathrm{r}=-0.83, \mathrm{p}=0.042)$.

Higher noradrenaline and estradiol contents were revealed in Indian population men as compared with Ukrainian ones (Figure 1,2).

After division of all participants into 3 subgroups depending on neuroticism level, in persons with high neuroticism the significant positive correlation between neuroticism and cortisol $(\mathrm{r}=+0.81, \mathrm{p}=0.004)$ and significant negative correlations between noradrenaline and neuroticism $(\mathrm{r}=-0.71, \mathrm{p}=0.034)$ and between noradrenaline and physical aggression $(\mathrm{r}=-0.70$, $\mathrm{p}=0.035$ ) were observed.

In individuals with middle neuroticism level the strong positive correlations between estradiol and neuroticism $(\mathrm{r}=+0.85, \mathrm{p}=0.014)$ and between testosterone and physical aggression $(\mathrm{r}=+0.93$, $\mathrm{p}=0.008$ ) were found.

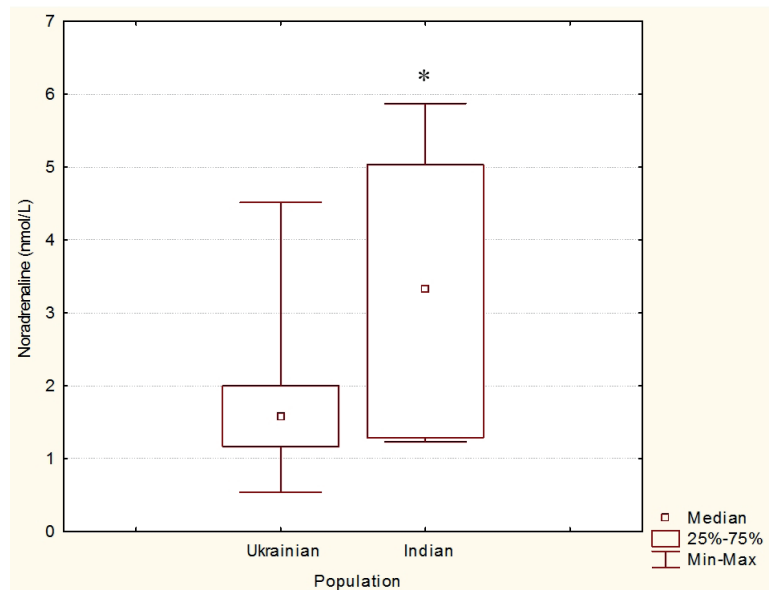

Figure 1. Noradrenaline level in blood serum of Indian and Ukrainian young men (Me [25\%; 75\%], min and max; $* \mathrm{P}<0.05)$ 


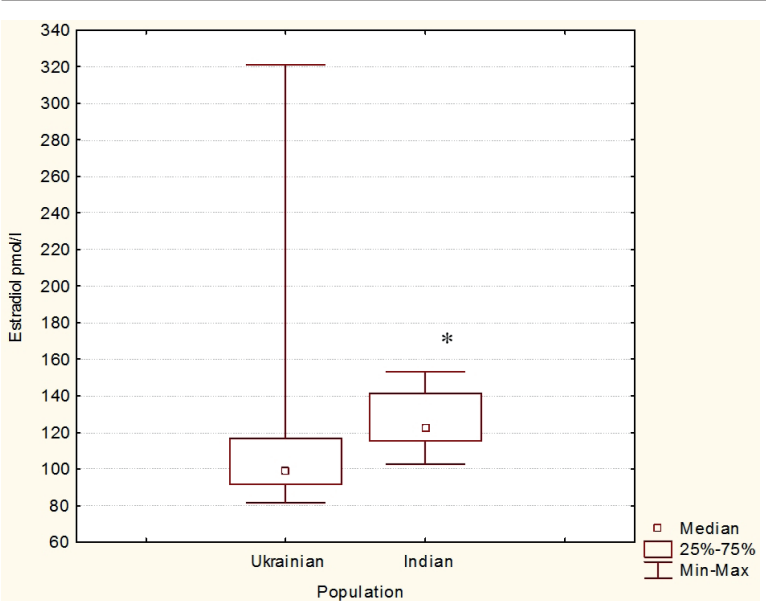

Figure 2. $\beta$-Estradiol level in blood serum of Indian and Ukrainian young men $(\mathrm{Me}[25 \% ; 75 \%]$, $\min$ and $\max ; * \mathrm{P}<0.05)$

We calculated the ratios of cortisol to testosterone, cortisol to noradrenaline, testosterone to noradrenaline. We compared these ratios in Ukrainian and Indian men, and also in persons with middle and high neuroticism. We performed correlation analysis between these ratios and all investigated parameters.

The significant negative correlation between cortisol to testosterone ratio and physical aggression was revealed in Ukrainian men $(\mathrm{r}=-0.57, \mathrm{p}=0.00142)$ and individuals with middle neuroticism $(r=-0.84, p=0.036)$. The significant positive correlation between cortisol to testosterone ratio and neuroticism was revealed

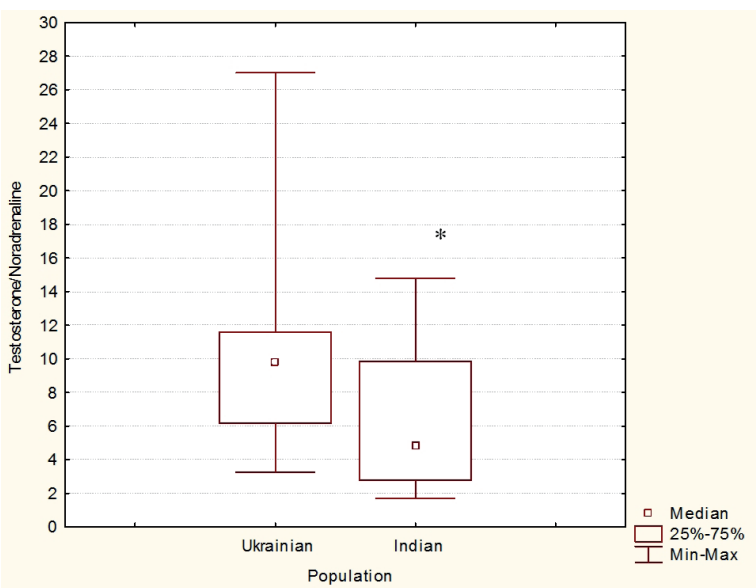

Figure 3. Testosterone to noradrenaline ratio in blood serum of Indian and Ukrainian young men (Me [25\%; 75\%], min and $\max ; * \mathrm{P}<0.05$ ) in persons with high neuroticism $(\mathrm{r}=+0.77$, $\mathrm{p}=0.0093$ ). High positive correlation was found between cortisol to testosterone and cortisol to noradrenaline ratios in Ukrainian men $(\mathrm{r}=+0.63$, $\mathrm{p}=0.0036$ ), and between cortisol to noradrenaline ratio and physical aggression in persons with high neuroticism $(r=+0.78, \mathrm{p}=0.0075)$.

It should be noted that strong positive correlation between testosterone to noradrenaline ratio and cortisol to noradrenaline ratio in all subgroups (Ukrainian men $-\mathrm{r}=+0.63, \mathrm{p}=0.004$; Indian men $-r=+0.80, p=0.00096)$; persons with high neuroticism $-\mathrm{r}=+0.79, \mathrm{p}=0.006$ ); individuals with middle neuroticism $-\mathrm{r}=+0.93, \mathrm{p}=0.0025$ ).

No difference was observed between cortisol to testosterone coefficients in Ukrainian and Indian men. In individuals with high and middle neuroticism no differences between cortisol to testosterone, between cortisol to noradrenaline, between testosterone to noradrenaline coefficients were revealed. But Ukrainian and Indian men differed by testosterone to noradrenaline $(\mathrm{p}=0.040076)$ and cortisol to noradrenaline $(\mathrm{p}=0.030169)$ ratios, those were higher in Ukranian men (Figure 3, 4).

\section{DISCUSSION}

During specific sensitive phases of early fetal and perinatal development the steroid sex

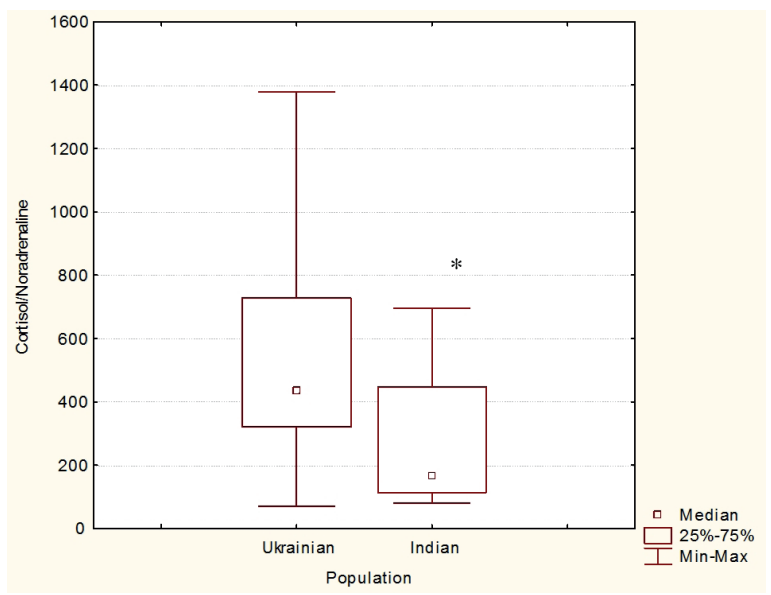

Figure 4 Cortisol to noradrenaline ratio in blood serum of Indian and Ukrainian young men (Me [25\%; 75\%], min and $\max ; * \mathrm{P}<0.05)$ 
hormones have organizing influence on both neuroendocrine system and brain mechanisms underlying gender-specific behavior [13].

Organizing effects during fetal life and activating effects of sex hormones on hypothalamic pituitary adrenal axis have been reported [14]. Both androgen receptors and androgen conversion to estrogen have an organizing influence of on hypothalamic pituitary adrenal axis habituation to repeated psychogenic stress [15]. So, androgens affect sensitivity to stress.

On the other hand, hypothalamic pituitary adrenal axis hormones play the important role in mediation of prenatal stress induced disorders of brain development programming processes. The diminishing of sex-specific pattern of the protein fractions (on the 5th postnatal day), steroid aromatase activity (on the 10th postnatal day) in the brain preoptic area, and a decrease of male copulatory behavior, hypothalamic noradrenaline and plasma corticosterone responses to an acute stress, an increase in hypothalamic pituitary adrenal responses to noradrenergic stimulation in adulthood were revealed in prenatally stressed males [16].

Modulation of long-term alterations in synaptic strength, gene transcription and other processes by noradrenaline suggests a potentially critical role of this mediator system in experience-dependent alterations in neural function and behavior [17]. It is possible that noradrenaline is one of inducers of androgendependent sexual differentiation of brain [18].

Almost all of noradrenergic fibers begin in the brain stem nuclei. Half of them belong to the locus coeruleus [19]. Locus coeruleus has dense excitatory projections to cortex, hippocampus, amygdale, thalamus, hypothalamus, dorsal raphe nucleus serotoninergic neurons [20]. Despite the wide noradrenergic projection from locus coeruleus to cortex, the only cortical structure projecting back to the locus coeruleus is medial prefrontal cortex [21].

The exposure to stress is associated with locus coeruleus excitation and raising of noradrenaline release and renovation in brain areas having noradrenergic innervation [22]. Under normal conditions, noradrenergic systems can influence the magnitude of the hypothalamic pituitary adrenal axis response to stress [23]. Noradrenaline released in the frontal cortex is important modulator of the basal and stressinduced output of the autonomic nervous system [24].

All the above mentioned substantiates the choice for the study namely of these hormones and the possibility of studying peripheral catecholamines instead of brain catecholamines.

According to obtained data, no interrelation between investigated parameters and neuroticism was found both in total group of participants and men of every population, but in Indian men the strong negative correlation between noradrenaline and physical aggression was observed.

Due to literature data about relation of both impulsive [2,3] and premeditated [3] aggressions to high neuroticism, we divided the participants into 3 subgroups according to neuroticism level and examined the correlations within these subgroups.

In persons with high neuroticism the significant positive correlation between neuroticism and cortisol and significant negative correlations between noradrenaline and neuroticism, and between noradrenaline and physical aggression were observed. Our results on the negative correlation between the content of noradrenaline and neuroticism are consistent with the literature data on the relationship between polymorphism of the dopamine betahydroxylase promoter gene and impulsivity [25]. According to these results homozygosity at this locus (TT genotype at DBH-1021) appears to increase the risk towards personality traits related to impulsiveness and aggression [25]. Dopamine $\beta$-hydroxylase catalyzes the conversion of dopamine to noradrenaline and plays a critical role in maintaining balance of dopamine and noradrenaline in cortex. The $\mathrm{T}$ allele decreases gene transcription and slows the rate of dopamine conversion to noradrenaline 
[26]. So, the decrease of noradrenaline leads to higher impulsivity.

Results on negative correlation between noradrenaline and physical aggression may be explained by important role of noradrenaline in executive function. Norepinephrine activity impacts all four of the cognitive processes that participate in executive function (response inhibition, attention and two types of cognitive flexibility, set-shifting, and reversal learning) [26]. Executive function provides the organism adaption through the regulation of reflexive reactions to current salient stimuli to achieve the goals requiring complex behaviors.

Higher noradrenaline and estradiol contents were revealed in Indian population men as compared with Ukrainian ones. We believe that increased content of noradrenaline in men of Indian population provides the potent control of neuroticism and physical aggression expression.

In individuals with middle neuroticism level the strong positive correlations between estradiol and neuroticism and between testosterone and physical aggression were found. Correlation analysis between investigated parameters in persons with low neuroticism was not carried out because of few such individuals. Obtained results indicate the different contribution of cortisol and estradiol to formation of high and middle neuroticism levels.

In the literature, there is evidence that not the absolute content of hormones, in particular testosterone or cortisol, but their ratio is important for the formation of dominance or the development of aggression. Testosterone positively correlates with the dominance in individuals with low cortisol. In individuals with high cortisol, the relationship between testosterone and dominance is blocked and even acquires the opposite direction [27]. Hormonalserotoninergic theory of the development of impulsive aggression in humans includes the effects of high testosterone to cortisol ratio on amygdala and low serotonin in the prefrontal cortex [28]. Taking into account these findings and literature data on the noradrenaline influence on the magnitude of the hypothalamic pituitary adrenal axis response to stress [23], on the selective effects of gonadectomy and hormone replacement in adult male rats on norepinephrine transporter sites in the cerebral cortex [29], we calculated the ratios of cortisol to testosterone, cortisol to noradrenaline, testosterone to noradrenaline.

The general tendency was found in all subgroups (Ukrainian and Indian men persons with high and middle neuroticism): strong positive correlation between testosterone to noradrenaline ratio and cortisol to noradrenaline ratio. Ukrainian and Indian men differed by testosterone to noradrenaline and cortisol to noradrenaline ratios. These ratios were higher in Ukranian men. Interpretation of this tendency requires the same research in other populations.

Thus, the positive correlation between neuroticism and cortisol and negative correlations between noradrenaline and neuroticism, noradrenaline and physical aggression were observed in persons with high neuroticism. The positive correlations between estradiol and neuroticism and between testosterone and physical aggression were found in individuals with middle neuroticism level. The strong negative correlation between noradrenaline and physical aggression was observed in Indian men. Higher noradrenaline and estradiol contents were revealed in Indian population men as compared with Ukrainian population men. The increased content of noradrenaline in men of Indian population appears to provide the potent control of neuroticism and physical aggression expression. In all subgroups (Ukrainian and Indian men, persons with high and middle neuroticism) the strong positive correlation between testosterone to noradrenaline ratio and cortisol to noradrenaline ratio was found.

The authors of this study confirm that the research and publication of the results were not associated with any conflicts regarding commercial or financial relations, relations with organizations and/or individuals who may have been related to the study, and interrelations of co-authors of the article. 
Л.Д. Попова, И.М. Васильева, О.А. Наконечная

ПОПУЛЯЦИОННЫЕ ОСОБЕННОСТИ СОДЕРЖАНИЯ ПОЛОВЫХ ГОРМОНОВ И ГОРМОНОВ СТРЕССА В СЫВОРОТКЕ КРОВИ МОЛОДЫХ МУЖЧИН

Исследовано содержание тестостерона, эстрадиола, норадреналина, адреналина, кортизола в сыворотке крови у молодых мужчин украинской и индийской популяций и взаимосвязь этих показателей, нейротизма и физической агрессии. Более высокие концентрации норадреналина и эстрадиола были выявлены у мужчин индийской популяции по сравнению с мужчинами украинской популяции. Как в общей группе участников, так и у последних не было обнаружено взаимосвязи исследуемых параметров и нейротизма, но у мужчин индийской популяции наблюдалась сильная отрицательная корреляция между содержанием норадреналина и физической агрессией. У лиц с высоким уровнем нейротизма обнаружены отрицательные корреляционные связи между норадреналином и нейротизмом, между норадреналином и физической агрессией, а также положительная корреляция между нейротизмом и кортизолом. У лиц со средним уровнем нейротизма были сильные положительные корреляции между содержанием эстрадиола и нейротизмом, а также между содержанием тестостерона и физической агрессией. Полученные результаты указывают на различный вклад кортизола и эстрадиола в формирование высокого и среднего уровней нейротизма. Возможно, что повышенная концентрация норадреналина у мужчин индийской популяции обеспечивает мощный контроль экспрессии нейротизма и физической агрессии. Во всех подгруппах (у мужчин украинской и индийской популяций, у лиц с высоким и средним уровнем нейротизма) была обнаружена сильная положительная корреляция между соотношениями тестостерона к норадреналину и кортизола к норадреналину.

Ключевые слова: половые гормоны; гормоны стресса; нейротизм; физическая агрессия; мужчины.

\section{Л.Д. Попова, І.М. Васильєва, О.А. Наконечна}

\section{ПОПУЛЯЦЙНІ ОСОБЛИВОСТІ ВМІСТУ СТАТЕВИХ ГОРМОНІВ ТА ГОРМОНІВ СТРЕСУ У СИРОВАТЦІ КРОВІ МОЛОДИХ ЧОЛОВІКІВ}

Досліджено вміст тестостерону, естрадіолу, норадреналіну, адреналіну, кортизолу в сироватці крові молодих чоловіків української та індійської популяцій, а також взаємозв'язок цих показників, нейротизму та фізичної агресії. Більш високі рівні норадреналіну та естрадіолу було виявлено у чоловіків індійської популяції порівняно з чоловіками української популяції. Як у загальній групі учасників, так і у останніх не виявлено взаємозв'язку досліджених показників та нейротизму, однак у чоловіків індійської популяції спостерігалася негативна кореляція між вмістом норадреналіну та фізичною агресією. У осіб 3 високим рівнем нейротизму спостерігалися негативні кореляційні зв'язки між норадреналіном та нейротизмом і фізичною агресією та позитивна кореляція між нейротизмом та кортизолом. У осіб з середнім рівнем нейротизму було виявлено сильні позитивні кореляційні зв'язки між естрадіолом і нейротизмом та між тестостероном і фізичною агресією. Отримані результати вказують на різний внесок кортизолу та естрадіолу у формування високого та середнього рівнів нейротизму. Можливо, що підвищений вміст норадреналіну у чоловіків індійської популяції забезпечує потужний контроль експресії нейротизму та фізичної агресії. У всіх підгрупах (у чоловіків української та індійської популяцій, у осіб з високим та середнім рівнями нейротизму) виявлено сильну позитивну кореляцію між співвідношеннями тестостерону до норадреналіну та кортизолу до норадреналіну.

Ключові слова: статеві гормони; гормони стрессу; нейротизм; фізична агресія; чоловіки.

Харківський начіональний медичний університет; e-mail:popova_ld@ukr.net

\section{REFERENCES}

1. Neumann ID, Veenema AH, Beiderbeck DI. Aggression and anxiety: social context and neurobiological links. Front Behav Neurosci. 2010;4:1-12. Cited in PubMed; PMID 20407578.

2. Gauthier KJ, Furr RM, Mathias CW, Marsh-Richard DM, Dougherty DM. Differentiating impulsive and premeditated aggression: self and informant perspectives among adolescents with personality pathology. J Pers Disord. 2009;23(1):76-84. doi: 10.1521/pedi.2009.23.1.76.

3. Stanford MS, Houston RJ, Villemarette-Pittman NR, Greve KW. Premeditated aggression: Clinical assessment and cognitive psychophysiology. Personality and Individual Differences. 2003;34(5):773-81. doi: 10.1016/ S0191-8869(02)00070-3.

4. Wingfield JC, Lynn S, Soma KK. Avoiding the 'costs' of testosterone: ecological bases of hormone-behavior interactions. Brain Behav. 2001;57:239-51. Cited in PubMed; PMID 11641561.

5. Chichinadze KN, Dominiadze TR, Matitaischvili T, Chichinadze NK, Lazaraschvili AG. Is the blood plasma testosterone level linked with aggressive behaviour of prisoner men? Bul Exp Biol Med. 2010;149(1):11-3.

6. Roselli CE, Liu M, Hurn PD. Brain aromatization. Classical roles and new perspectives. Semin Reprod Med. 2009;27(3):207-17. Cited in PubMed; PMID19401952.

7. Blakemore SJ, Burnett S, Dahl RE. The role of puberty in the developing adolescent brain. Hum Brain Mapp. 2010;31(6):926-33. doi: 10.1002/hbm.21052.

8. van der Vegt BJ, Lieuwes N, Cremers TI, de Boer SF, Koolhaas JM. Cerebrospinal fluid monoamine and 
metabolite concentrations and aggression in rats. Horm Behav. 2003;44(3):199-208. Cited in PubMed; PMID 14609542.

9. Lee S, Jeong J, Kwak Y, Park SK. Depression research: where are we now? Mol Brain. 2010;3:8. Cited in PubMed; PMID 20219105.

10. Thompson BL, Stanwood GD. Pleiotropic effects of neurotransmission during development: modulators of modularity. J Autism Dev Disord. 2009;39(2):260-68. Cited in PubMed; PMID 18648918.

11. Foote SL, Morrison JH. Extrathalamic modulation of cortical function. Annu Rev Neurosci. 1987;10:67-95. Cited in PubMed; PMID 3551766.

12. de Kloet ER, Joëls M, Holsboer F. Stress and the brain: from adaptation to disease. Nat Rev Neurosci. 2005;6:463-73.

Hutchison JB. Gender-specific steroid metabolism in neural differentiation. Cell Mol Neurobiol. 1997;17(6):603-26. Cited in PubMed; PMID 9442349.

13. Swaab DF, Bao A.M, Lucassen PJ. The stress system in the human brain in depression and neurodegeneration. Ageing Res Rev. 2005;4(2):141-94. Cited in PubMed; PMID 15996533.

14. Bingham B, Gray M, Sun T, Viau V. Postnatal blockade of androgen receptors or aromatase impair the expression of stress hypothalamic-pituitary-adrenal axis habituation in adult male rats. Psychoneuroendocrinology. 2011;36(2):249-57. doi: 10.1016/j.psyneuen. 2010.07.015.

15. Reznikov AG, Nosenko ND, Tarasenko LV, Sinitsyn PV, Lymareva AA. Prenatal dexamethasone prevents early and long-lasting neuroendocrine and behavioral effects of maternal stress on male offspring. Fiziol $\mathrm{Zh}$. 2008;54(5):28-39. Cited in PubMed; PMID 19058510.

16. Berridge CW, Waterhouse BD. The locus coeruleusnoradrenergic system: modulation of behavioral state and state-dependent cognitive processes. Brain Res Brain Res Rev. 2003;42(1):33-84. Cited in PubMed; PMID 12668290.

17. Reznikov AG. Mechanisms of development of functional pathology of reproduction and adaptation in early ontogenesis. Zh AMN of Ukraine. 1998;4(2):216-33.

18. Prokopova I. Noradrenalin and behavior. Cesk. Fysiol. 2010;59(2):51-8. Cited in PubMed; PMID 21254660.

19. Samuels ER, Zabadi ES. Functional neuroanatomy of the noradrenergic locus coeruleus: its roles in the regulation of arousal and autonomic function. Part I: Principles of functional organization. Curr. Neuropharmacol. 2008;6(3):235-53. doi: 10.2174/157015908785777229.

20. Lu Y, Simpson KL, Weaver KJ, Lin RC. Differential distribution patterns from medial prefrontal cortex and dorsal raphe to the locus coeruleus in rats. Anat Rec (Hoboken). 2012;295(7):1192-201. Cited in PubMed PMID: 22674904. doi: 10.1002/ar.22505.

21. van der Vegt BJ, Lieuwes N, Cremers TI, de Boer SF, Koolhaas JM. Cerebrospinal fluid monoamine and metabolite concentrations and aggression in rats. Horm Behav. 2003;44(3):199-208. Cited in PubMed; PMID 14609542.

22. Young EA, Abelson JL, Cameron OG. Interaction of brain noradrenergic system and the hypothalamic-pituitaryadrenal (HPA) axis in man. Psychoneuroendocrinology. 2005;30(8):807-14. Cited in PubMed; PMID:15896919. doi:10.1016/j.psyneuen.2005.03.009

23. Funk D, Stewart J. Role of catecholamines in the frontal cortex in the modulation of basal and stress-induced autonomic output in rats. Brain Res. 1996;741(1-2):2209.

24. Hess C, Reif A, Strobel A, Boreatti-Hümmer A, Heine M, Lesch K P , Jacob CP. A functional dopamine-betahydroxylase gene promoter polymorphism is associated with impulsive personality styles, but not with affective disorders. J Neural Transm (Vienna). 2009;116(2):12130. doi: 10.1007/s00702-008-0138-0.

25. Logue SF, Gould TJ. The neural and genetic basis of executive function: attention, cognitive flexibility, and response inhibition. Pharmacol Biochem Behav. 2014;123:45-54. Cited in PubMed; PMID:23978501. doi: 10.1016/j.pbb.2013.08.007.

26. Mehta PH, Josephs RA, "Testosterone and cortisol jointly regulate dominance: evidence for a dual-hormone hypothesis". Horm Behav. 2010;58(5):898-906.

27. Stefansson J, Chatzittofis A, Nordström P et al. "CSF and plasma testosterone in attempted suicide". Psychoneuroendocrinology. 2016;74:1-6.

28. Meyers B, Kritzer MF. In vitro binding assays using (3)H nisoxetine and (3)H WIN 35,428 reveal selective effects of gonadectomy and hormone replacement in adult male rats on norepinephrine but not dopamine transporter sites in the cerebral cortex. Neuroscience. 2009;159(1):271-82. doi: 10.1016/j.neuroscience.2008.12.010. 